\title{
Prevalence of Helicobacter Pylori Infection and Associated Factors Among Gastritis Patents in Yekatit 12 Teaching Hospital Addis Ababa Ethiopia
}

Awraris Hailu

Debre Berhan University

Bekureamanuel Sileshi

Debre Berhan University

Hazaratali Panari ( $\square$ alipanari007@gmail.com )

Debre Berhan University

\section{Research Article}

Keywords: Antigen, Arada sub-city, Gastritis and Helicobacter pylor

Posted Date: December 14th, 2020

DOI: https://doi.org/10.21203/rs.3.rs-114088/v1

License: (c) (i) This work is licensed under a Creative Commons Attribution 4.0 International License.

Read Full License 


\section{Abstract}

Introduction: Helicobacter pylori colonize the stomach of about 50\% of the world's human population and infection is more in clients with dyspeptic conditions and its associated with the severity of gastritis. The present study revealed that the magnitude of $\mathrm{H}$. Pylori and burden of the bacterial infection as well as the contribution of $\mathrm{H}$. Pylori for gastritis and also assesses the current prevalence of $\mathrm{H}$. Pylori infection.

Objective: To evaluate the prevalence of Helicobacter Pylori infection and associated factors among gastritis patents in Yekatit 12 Hospital.

Methodology: An institutional based cross-sectional study was conducted in Yekatit 12 teaching hospital Addis Ababa city, Ethiopia. The participants were those patients come to the hospital for treatment of gastritis and send to the laboratory to confirm Helicobacter pylori infection in the data collection period. A total of 394 participants were interviewed by using a structured pre tested questionnaire. The data were coded and entered into Epi Data 3.1 version, cleaned and exported to version 20, SPSS. Multiple Logistic regression was used to estimate Adjusted (AORs) with a 95\% confidence interval (Cl) of positive responses to the different risk factors. P-value $<0.05$ was considered as significant.

Result: The total occurrence of H. Pylori in observers was $25.9 \%$. Regarding income of family, those participants who have less income and living in rural areas were extra prone to be infected with $\mathrm{H}$. Pylori $(\mathrm{AOR}=5.857, \mathrm{Cl} 95 \%=1.389-24.686, \mathrm{P}=0.016$ and $\mathrm{AOR}=3.663, \mathrm{Cl} 95 \%=1.068-12.557, \mathrm{P}=0.039)$ respectively. Further, the prevalence of study was significant association with participants who had experience of gastrointestinal illness, mouth to mouth kissing, unable to hand wash regularly before meal and after latrine used $(\mathrm{AOR}=4.270,95 \% \mathrm{Cl}=1.785-10.21, \mathrm{P}=0.01, \mathrm{AOR}=53.085,95 \% \mathrm{Cl}=16.185-174.114$, $\mathrm{P}=0.000, \mathrm{AOR}=7.316,95 \% \mathrm{Cl}=1.944-27.536, \mathrm{P}=0.003, \mathrm{AOR}=3.374,95 \% \mathrm{Cl}=1.024-11.114, \mathrm{P}=0.046)$ respectively.

Conclusion and recommendation: The finding shows that $\mathrm{H}$. Pylori infection was significantly associated with occupational status,gender, smoking tobacco and hand washing regularly before meal and after toilet. I recommend making clean and saving the work place; regular hand wash, before food preparation, before feeding and after latrine. A health professional should give health education by using different media about the transition and health biro also should give emphases.

\section{Background}

Helicobacter pylori formerly known as Campylobacter Pylori bacterium usually present in the stomach. The bacterium present in a people suffering with gastric ulcer and chronic gastritis and previously not believed to have a microbial cause $(1,2)$ However, above $80 \%$ of persons infected are asymptomatic, and it may show a main part in the normal stomach ecology (3). 
Helicobacter pylori infection is a major global public health problem recently, which affects nearly 50 to $75 \%$ of world population. About $70 \%$ of people in developing countries with peptic ulcer diseases and slightly lower in the developed countries (4).The global magnitude of H. Pylori was $70.1 \%$ in Africa, $69.4 \%$ in western Asia, 34.3\%

Western Europe, 37.1\% North America (5). Studies in Ethiopia show about 52.2\% of Ethiopian peoples are infected with $\mathrm{H}$. Pylori. Bacterial infection of distribution is different within the regions (6).

The overall burden of $\mathrm{H}$. Pylori is suggested to be significantly associated with low socioeconomic condition, unhygienic sources of water, overcrowding, family contact with infected persons, increasing household numbers, open-air defecation, absence of hand washing after toilet and gastrointestinal symptoms are positively associated with $\mathrm{H}$. Pylori infection $(6,7)$.

Colonization in early life by $\mathrm{H}$. Pylori has been found to influence affected persons to the advancement of malnutrition and improvement of faltering (4) and also have been involved in several extra- gastro duodenal conditions, like cardiac diseases, prolonged hepatic diseases, anaemia, and diabetes mellitus (7). The bacterium was high in patients with dyspeptic disorders and was associated with the severity of gastritis (8). H.Pylori eradication treatment is cost beneficial, it will also prevent the spread of bacterial in the future. Eradication of $\mathrm{H}$. Pylori infection in the public gives collective lasting benefit, with a constant decrease in the improvement of dyspepsia up to 7 years (9). The drug resistance rate of the bacterium becomes increased from triple treatment (omeprazole, amoxicillin and metronidazole) based to another triple treatment (omeprazole, amoxicillin and clatitromicine); however in Morocco high rate of H.pylori resistance to clarithromycin has been reported (7).

\section{Material And Method}

\section{Study area and Design}

The research was lead in Arada Sub-city, Yekatit 12 teachings specialized hospital Addis Ababa Ethiopia located Around Sdist kilo. A cross-sectional study design was applied from 28 February to 30 April 2020. Those patients who came to Yekatit 12 teaching hospitals for treatment of dyspepsia or gastritis and send to the laboratory to confirm $\mathrm{H}$. Pylori states during the data collection period were taken as source population. The study population was selected patients with symptoms of gastritis and dyspepsia undertaking laboratory investigation for $\mathrm{H}$. Pylori.

Sample size and Sample size determination Formula

$\mathrm{n}=(Z \alpha / 2) 2 *(1-p) \mathrm{d} 2$

n = sample size

$P=0.368$ 
$10 \%$ Non-response rate $=10 * 358=35.8$ (Confidence interval which is 1.96$)$ Marginal Error $=5 \%=0.05$

The minimum sample size and the prevalence $(p)$ taken was $36.8 \%$, from earlier study in Jasmin internal medicine and pediatrics clinic at Addis Ababa, Ethiopia which is given a large size sample compared to the other H.Paylori prevalence study (14) with a marginal error of 5 , and a $95 \%$ confidence interval. Based on this estimation the sample size was 358 by adding $10 \%$ non- response rate we have to gate 394 samples. The participant selected from the gastritis patients in the hospital come to treatment in both out patient and in patient department. All the patients who have signs and symptom of gastritis and who are volunteers, will include in the sample.

To calculate sample size for associated factor, I used Epi-info version 7.2 and Sample size calculation by epi info for associated factor lower than the 385, therefor I take the previous one 385.

\section{Data collection procedure}

Participants were selected from the medical recorded books; emergency recorded books and admitted patent recorded books of Yekatit 12 teaching hospital. All patients from February 28/2020-Aprial 30/2020 come to Yekatit 12 teaching Hospital for gastritis treatments or admitted by gastritis symptom are selected. The first gastritis patient in every out-patients, admitted patients and emergency patients selected by lottery methods then, every other gastritis patient selected from the recorded books were selected. All patients who needed to send to laboratory to confirm H. pylori status was participated voluntarily in the study.

\section{Collection of Data}

Information was gathered by four BSC nurse and two Health officers were participated as a supervisor. Participants were interviewed about sociodemographic profile, environmental situations, individual habits and the complication of H.Pylori. Data were collected from patient by using a pre tasted and structured questionnaire.

\section{Variables}

Dependent: H. Pylori status

Independent: Sociodemographic factors like age, sex, education, etc. hygiene practice like hand washing, environment and personal habits like drinking alcohol, smoking etc. Complications of H. Pylori (gastric outlet obstruction, gastric cancer, peptic ulcer disease)

\section{Inclusion criteria}

1) Patients with age $>18$. 
2) Presence of minimum 2 manifestations like upper abdominal pain, bloating , nausea, vomiting.

3) Persistent symptoms occurring at least 3 times per week in $>3$ months in the year or years preceding the study.

4) Absence of nocturnal or postprandial symptoms of gastro esophageal reflux.

5) No previous abdominal surgery except for uncomplicated appendectomy, cholecystectomy.

\section{Exclusion criteria}

Different other illness and age below 18 years old will excluded.

\section{Data quality control}

Stool antigen test is inexpensive and more convenient. It is a simple and accurate test using monoclonal antibodies specific for $\mathrm{H}$. Pylori antigens and potentially less expensive than the urea breath test. The best of these tests are as accurate as other diagnostic methods (10). The sensitivity, specificity, positive and negative predictive values of $\mathrm{HpSA}$ were found to be $98 \%, 100 \%, 100 \%$, and $96.5 \%$, respectively (11).

The pretesting of questionnaire was made with the same type of patients who are not in the study then necessary changes have been made. For data collector and supervisor training has been given and pretest was done in Debre Berhan referral hospital.

The stool samples were tested according to the procedure. A samples were collected from each participant. A lesser quantity of the stool sample was transmitted to a vial with diluents, strongly agitated for 15 seconds and after that 2to3 drops were mixed into the round window of the test cassette. The findings were read after 15 minutes and the results are read based on the appearance. The presence of two lines, C (control) and T (test), specifies a positive test, and presence of only one line, C (control) shows a negative result.

\section{Statistical analysis}

Data were coded, The collected information entered into the Epi-data 3.1,coded and analyzed using version 20 SPSS.The presence of an association between dependent and independent variables was checked by Binary logistic regression analysis. Variables that showed below 0.25 in binary logistic regression were selected for further analysis with multiple logistic regressions and hosmer-lemenshow goodness of fit above 0.05 was considered as a fit of model. A P-value less than 0.05 were taken as statistically significant.

\section{Ethical considerations}

The studies have been approved by the Ethical committee of Dere Berhan University (Reference No: DBUMF 053-009; presented in Annexure-l) and permission was obtained from Yekatit 12 teaching referral 
hospital administrator (Reference No: Y12HMC-20/20; presented in Annexure-II). Moreover, informed consent has been obtained from participants who are involved in the study and all methods were performed in accordance with the relevant guidelines and regulations..

\section{Dissemination of the results}

The finding of the study will be submitted to the Debre Berhan University College of health science department of public health Yekatit 12 teaching hospital and ministry of health Addis Ababa, Ethiopia.

\section{Results}

In this study a total of 394 individuals were participated with a response rate of $100 \%$. The mean and standard deviation age of this variable was 39.31 years and \pm 16.905 years respectively. From this 163 $(41.3 \%)$ were males and $231(58.63 \%)$ were females (Table 1$)$. Above half of the total participants 212 $(53.8 \%)$ were living in urban; $142(36 \%)$ were living in semi urban and $40(10.2 \%)$ were living in rural (Table 2 see detail). 
Table 1

Socio-demographic characteristic of gastritis patients of Yekatit 12 teaching hospital, Addis Ababa Ethiopia, 2020 ( $n=394$ ).

\begin{tabular}{|c|c|c|c|}
\hline \multicolumn{2}{|l|}{ Variable } & \multirow{2}{*}{$\begin{array}{l}\text { Frequency } \\
163\end{array}$} & \multirow{2}{*}{$\begin{array}{l}\text { Percent } \\
41.37 \%\end{array}$} \\
\hline Gender & Male & & \\
\hline & Female & 231 & $58.63 \%$ \\
\hline \multirow[t]{5}{*}{ Age } & $18-25$ & 103 & $26.1 \%$ \\
\hline & $26-35$ & 100 & $25.4 \%$ \\
\hline & $36-45$ & 63 & $16 \%$ \\
\hline & $46-55$ & 51 & $12.9 \%$ \\
\hline & Above 56 & 77 & $19.5 \%$ \\
\hline \multirow[t]{3}{*}{ Residence } & Urban & 212 & $53.8 \%$ \\
\hline & Semi urban & 142 & $36.0 \%$ \\
\hline & Rural & 40 & $10.2 \%$ \\
\hline \multirow{4}{*}{$\begin{array}{l}\text { Marital } \\
\text { Status }\end{array}$} & Married & 247 & $62.7 \%$ \\
\hline & Unmarried & 91 & $23.1 \%$ \\
\hline & Divorced & 32 & $8.1 \%$ \\
\hline & Widowed & 24 & $6.1 \%$ \\
\hline \multirow{4}{*}{$\begin{array}{l}\text { Educational } \\
\text { Status }\end{array}$} & Illiterate & 40 & $10.2 \%$ \\
\hline & Primary school & 144 & $36.5 \%$ \\
\hline & Secondary school & 64 & $16.2 \%$ \\
\hline & College/university & 146 & $37.1 \%$ \\
\hline \multirow{4}{*}{$\begin{array}{l}\text { Occupational } \\
\text { Status }\end{array}$} & Governmental & 166 & $42.1 \%$ \\
\hline & Non-Governmental & 58 & $14.7 \%$ \\
\hline & Private & 136 & $34.5 \%$ \\
\hline & Other & 34 & $8.6 \%$ \\
\hline \multirow{3}{*}{$\begin{array}{l}\text { Family } \\
\text { Number }\end{array}$} & Three and below & 199 & $50.5 \%$ \\
\hline & Four to six & 169 & $42.9 \%$ \\
\hline & Above six & 26 & $6.6 \%$ \\
\hline
\end{tabular}


In this study history of gastritis clients were reported by 161 (40.9\%). Out of this 23 (14.3\%) participants have a history of gastritis for about less than one year; 75 (44.6\%) participants have a history of gastritis for about one to three years; $41(25.5 \%) \%$ ) participants has history of gastritis for about three to five years and $22(13.7 \%)$ participants has history of gastritis for about above five years.

\section{Prevalence Of Helicobacter Pylori}

The total prevalence of H.Pylori infection among the participants was $25.9 \%$. The proportion of H. Pylori was more in females than males $(60.8 \%$ versus $39.2 \%)$. However, the difference was not statistically significant $(p=0.608)$ (see Fig. 1).

Concerning complication of Helicobacter Pylori from the total $102 \mathrm{H}$.Pylori positive patients about 90 $(88 \%)$ of the participant have a medical complication and about $12(11.76 \%)$ of the participant had a surgical complications. Out a total of $102 \mathrm{H}$.Pylori positive participants on average 1073.8299 Ethiopian Birr were lost for treatment and 5 days were lost for treatment within one year.

\section{Factors associated with Helicobacter Pylori}

This study has shown a number of risk factors for $\mathrm{H}$. Pylori infection. Patient variables, including socioeconomic characteristics, were examined for association with H.Pylori infection (Table 2). Clients who have been habits of mouth to mouth kiss; previous history gastritis; clients who use tanker water for drink and clients who didn't hand wash before meals and after toilet had statistically significant $(\mathrm{p}<$ 0.0.05) associations with H.pylori.

Above half of the total participants 212 (53.8\%) were living in urban about 49.02\% (50/102) were H.Pylori positive; out of $142(36.04 \%)$ were living in semi-urban About $33(32.4 \%)$ were H.Pylori positive and out of $40(10.2 \%)$ living in rural about $19(18.63 \%)$ were H.Pylori positive which is statistically significant compared to urban $(\mathrm{AOR}=0.039, \mathrm{P}=\mathrm{Cl} 95 \%=1.068-12.557, \mathrm{P}=0.039)$. Out of $206(52.3 \%)$ of study participants had monthly income 2000 to 4000 Ethiopian Birr, about 49 (49.04\%) of H.Pylori positive; out of $105(26.6 \%)$ of study participants had monthly income less than 2000 Ethiopian Birr, about 39 (38.23\%) were H.Pylori positive, which is the significantly associated (AOR $=5.857, \mathrm{Cl} 95 \%=1.389-24.686$, $\mathrm{P}=0.016)$ and out of $83(21.1 \%)$ study participants had monthly income greater than 4000 Birr about $14(13.7 \%)$ of H.Pylori positive. Regarding to occupational status participants who works in nongovernmental and in private organization has significant association with H.Pylori compared to governmental organization $(\mathrm{AOR}=8.975,95 \% \mathrm{Cl}=2.268-38.508, \mathrm{P}=0.002$ and $\mathrm{AOR}=17.326,95 \% \mathrm{Cl}=$ $2.432-25.866, P=0.001)$ respectively. Participants who have family number of $4-6$ and Above 6 has no significantly associated with H.Pylori infection compared to family number less than $3(p=0.589$ and $0.369)$ respectively.

Concerning the habit and behavioral factor of Helicobacter pylori alcohol drunker 74.5\% (76/102) were H.Pylori positive out of 168 drunker participants; out of 48 smoker gastritis patients $30.4 \%(31 / 102)$ were 
H.pylori positive; out of 39 khat chewer gastritis clients $11.76 \%$ (12/102) were H.pylori positive however the difference were not statistically significant (Table 2). 
Table 2

Distribution of $\mathrm{H}$. Pylori infection and its association with risk factors among gastritis patients at Yekatit 12 teaching hospital.

\begin{tabular}{|c|c|c|c|c|c|c|c|}
\hline Variables & Total & $\begin{array}{l}\text { Stool } \\
\text { antigen }\end{array}$ & COR & $\begin{array}{l}P \text { - } \\
\text { value }\end{array}$ & AOR & $\begin{array}{l}\mathrm{P}- \\
\text { value }\end{array}$ & $95 \% \mathrm{Cl}$ \\
\hline & & Positive & Negative & & & & \\
\hline \multirow[t]{2}{*}{ Sex } & Male & 163 & 40 & 123 & 0.886 & 0.608 & \\
\hline & Female & 231 & 62 & 169 & & & \\
\hline \multirow[t]{6}{*}{ Age } & $18-25$ & 103 & 26 & 77 & 1.519 & 0.261 & 0.570 \\
\hline & $26-35$ & 100 & 33 & 67 & 2.216 & 0.029 & 2.252 \\
\hline & $36-45$ & & & & 1.663 & 0.214 & 2.000 \\
\hline & $46-55$ & 63 & 46 & 17 & 1.385 & 0.463 & 3.590 \\
\hline & Above & 77 & 14 & 63 & & & \\
\hline & 56 & & & & & & \\
\hline \multirow[t]{4}{*}{ Residence } & Urban & 212 & 50 & 162 & & & \\
\hline & Semi- & 142 & 33 & 109 & 0.981 & 0.940 & 1.631 \\
\hline & Urban & & & & & & \\
\hline & Rural & 40 & 19 & 21 & 2.931 & 0.002 & 3.663 \\
\hline \multirow[t]{5}{*}{ Income } & $<2000$ & 105 & 39 & 66 & 2.912 & 0.003 & 5.857 \\
\hline & $2000-$ & 206 & 49 & 157 & 1.538 & 0.200 & 1.685 \\
\hline & 4000 & & & & & & \\
\hline & Above & 83 & 14 & 69 & & & \\
\hline & 4000 & & & & & & \\
\hline \multirow[t]{5}{*}{ Marital status } & Married & 247 & 48 & 199 & 0.482 & 0.115 & \\
\hline & Unmarri & 91 & 32 & 59 & 1.085 & 0.867 & \\
\hline & Ed & & & & & & \\
\hline & Divorced & 32 & 14 & 18 & 1.556 & 0.431 & \\
\hline & Widow & 24 & 8 & 16 & & & \\
\hline \multirow{3}{*}{$\begin{array}{l}\text { Education al } \\
\text { status }\end{array}$} & Illiterate & 40 & 12 & 28 & 1.729 & 0.174 & \\
\hline & Primary & 144 & 43 & 101 & 1.718 & 0.050 & \\
\hline & School & & & & & & \\
\hline
\end{tabular}




\begin{tabular}{|c|c|c|c|c|c|c|c|}
\hline Variables & Total & $\begin{array}{l}\text { Stool } \\
\text { antigen }\end{array}$ & COR & $\begin{array}{l}\mathrm{P}- \\
\text { value }\end{array}$ & AOR & $\begin{array}{l}\mathrm{P}- \\
\text { value }\end{array}$ & $95 \% \mathrm{Cl}$ \\
\hline & Secondar & 64 & 18 & 46 & 1.579 & 0.188 & \\
\hline & $Y$ & & & & & & \\
\hline & $\begin{array}{l}\text { College or } \\
\text { universit }\end{array}$ & 146 & 29 & 117 & & & \\
\hline & $Y$ & & & & & & \\
\hline \multirow{6}{*}{$\begin{array}{l}\text { Occupatio } \\
\text { nal status }\end{array}$} & Governm & 166 & 26 & 140 & & & \\
\hline & ental & & & & & & \\
\hline & $\begin{array}{l}\text { Non- Governm } \\
\text { ental }\end{array}$ & 58 & 18 & 40 & 2.423 & 0.013 & 8.975 \\
\hline & Private & 136 & 44 & 92 & 2.575 & 0.001 & 7.931 \\
\hline & Other & 34 & 14 & 20 & 3.769 & 0.001 & 17.32 \\
\hline & & & & & & & 6 \\
\hline \multirow{3}{*}{$\begin{array}{l}\text { Family } \\
\text { number }\end{array}$} & $<3$ & 199 & 44 & 125 & 0.202 & 0.000 & 1.558 \\
\hline & $4-6$ & 169 & 44 & 125 & 0.258 & 0.002 & 2.078 \\
\hline & Above 6 & 26 & 15 & 11 & & & \\
\hline \multirow{2}{*}{$\begin{array}{l}\text { Drinking } \\
\text { Alcohol }\end{array}$} & Yes & 168 & 76 & 92 & 0.157 & 0.000 & 1.801 \\
\hline & No & 226 & 26 & 200 & & & \\
\hline \multirow{2}{*}{$\begin{array}{l}\text { Smoking } \\
\text { Tobacco }\end{array}$} & Yes & 48 & 31 & 17 & 7.063 & 0.000 & 1.403 \\
\hline & No & 346 & 71 & 275 & & & \\
\hline \multirow{2}{*}{$\begin{array}{l}\text { Khat } \\
\text { chewing }\end{array}$} & Yes & 39 & 12 & 17 & 14.444 & 0.000 & 2.574 \\
\hline & No & 280 & 63 & 275 & & & \\
\hline \multirow{2}{*}{$\begin{array}{l}\text { Mouth to } \\
\text { mouth kissing }\end{array}$} & Yes & 78 & 65 & 13 & 37.703 & 0.000 & \\
\hline & No & 316 & 37 & 279 & & & \\
\hline \multirow{2}{*}{$\begin{array}{l}\text { History of GI } \\
\text { illness }\end{array}$} & Yes & 160 & 77 & 83 & 7.756 & 0.000 & 4.270 \\
\hline & No & 209 & 25 & 234 & & & \\
\hline \multirow{2}{*}{$\begin{array}{l}\text { Hand wash before } \\
\text { meal }\end{array}$} & Yes & 344 & 68 & 276 & & & \\
\hline & No & 50 & 34 & 16 & 8.625 & 0.000 & 7.316 \\
\hline Hand wash after & Yes & 342 & 66 & 276 & & & \\
\hline
\end{tabular}




\begin{tabular}{|c|c|c|c|c|c|c|c|}
\hline Variables & Total & $\begin{array}{l}\text { Stool } \\
\text { antigen }\end{array}$ & COR & $\begin{array}{l}\mathrm{P}- \\
\text { value }\end{array}$ & AOR & $\begin{array}{l}\mathrm{P}- \\
\text { value }\end{array}$ & $95 \% \mathrm{Cl}$ \\
\hline & No & 52 & 26 & 16 & 9.409 & 0.000 & 3.374 \\
\hline \multirow[t]{3}{*}{$\begin{array}{l}\text { Water source to } \\
\text { drink }\end{array}$} & $\begin{array}{l}\text { Tanker } \\
\text { water }\end{array}$ & 19 & 12 & 7 & 5.667 & 0.000 & 9.917 \\
\hline & $\begin{array}{l}\text { Wheel } \\
\text { water }\end{array}$ & 9 & 5 & 4 & 4.132 & 0.038 & 0.312 \\
\hline & $\begin{array}{l}\text { Pipe } \\
\text { water }\end{array}$ & 366 & 85 & 281 & & & \\
\hline
\end{tabular}

\section{Discussion}

The total prevalence of $\mathrm{H}$. Pylori infection among participants was $25.90 \%$, which is similar to findings stated in Ethiopia $(12,13)$ however, its lower compared to other studies in Ethiopia and other studies in a different countries $(10,15,16,17)$. The variance in the prevalence of $\mathrm{H}$. Pylori infection may be due to differences in the study area, the work place, Environmental exposure, sample size,hygienic condition and differences in the socio-economic status of the study participants.

The prevalence of sex in female was $60.8 \%$ which was high compared to males $39.23 \%$ and this is almost similar to the study in Assosa General Hospital West Ethiopia (17) and it is also in another study the proportion of females is compared to male prevalence was higher $(13,18)$. But this study is in consistent with another study in Giggiga university Somalia regional states of Ethiopia. The reason for this contradictory result might be due to the difference female exposure to H.pylori infection within university might be high compared to males (16). People living in rural areas had significant association to H.Pylori infection when compared to urban and semi urban $(p=0.039)$ this is similar to the study in Assossa general hospital $(p=0.01)$.

In this study as seen in Table 2 revealed that $38.24 \% \%$ of the subjects in the lower socioeconomic class and $48.04 \%$ of those in the middle class have $\mathrm{H}$. Pylori positive when compared to only $13.7 \%$ of those in higher social class (Table 2$)$ showed that lower social class is significantly associated $(P<0.038)$ with increased H. Pylori infection. Similarly, a study done in Assosa general hospital and study in Nieria (19) found an increase in the risk of chronic $\mathrm{H}$. Pylori infection with decreasing socioeconomic status. Individuals from low socioeconomic class are more likely to be associated with H.pylori infection $(p<$ $0.05)$ that is more tendency for faecal contamination $(20,21)$.

Lifestyle, habit and personal hygiene have been recognized as important risk factors for acquisitions of H. Pylori infection. In this study, 74.5\% (76/102) participants were experienced alcohol drinking, but it was not significantly associate $(P=0.217)$ which is comparable with study in Gigiga university in Ethiopia about $66.7 \%(P=0.606)$ of H.Pylori positive participants were alcohol drunker $(16)$. However, there was a 
slight difference in other studies conducted in west Cameron 50.9\% of H.Pylori positive. The difference may due to the exposure, study area and sample size of the participants' difference.

Personal hygiene was a major factor to infect by H.Pylori, participants who unable to regularly hand wash after toilet were significant associations with H.Pylori infection $(P=0.046)$ which is similar with the study in Assosa general hospital $(p=0.034)(20)$. Poor sanitary practice is a risk factor for H.Pylori acquisition. Unable to hand washing before meal regularly has a significant association with H.pylori in this study ( $p$ $=0.003$ ) but no significant association in another study $(16,20)$. Use unsafe water for drink were a risk factor for acquisition of H.Pylori $(p=0.007)$ which is in line with the studies in Ethiopia $(12,16)$.

\section{Conclusion}

In this study $\mathrm{H}$. Pylori stool antigen detection rate was $25.9 \%$. It was significantly associated with private workers, smoking tobacco; habits of unable to hand wash regularly before meal; habits of unable to hand wash after toilet; habits of mouth to mouth kissing and low socioeconomic status. I recommend to make clean and save the work place; avoid mouth to mouth kissing, brushing teeth, not sharing of drinking glasses, spoons in feeding children, tobacco /cigarette and regular hand wash, before food preparation, before feeding and after latrine. A health professional should give health education by using different media about the transition and health biro also should give emphases. I recommend also to further larger community based study about the other risk factor and complication of H.paylori.

\section{Declarations}

\section{Ethical Approval and Consent to participate}

The studies have been approved by the Ethical committee of Debre Berhan University (Reference No: DBUMF 053-009; presented in Annexure-I) and permission was obtained from Yekatit 12 teaching referral hospital administrator (Reference No: Y12HMC-20/20; presented in Annexure-II). Moreover, informed consent has been obtained from participants who are involved in the study and all methods were performed in accordance with the relevant guidelines and regulations.

\section{Consent for publication}

It is not applicable.

\section{Availability of data and materials}

All data and materials are available with authors and same can be produced on request.

\section{Competing Interests}

Authors have declared that no competing interests exist. 


\section{Funding}

There is no any financial aid taken for this study.

\section{Acknowledgment}

The investigators owe a deep sense of gratitude to all those who have contributed to the successful completion of this endeavour.

\section{Authors information}

1. Dr.Awraris Hailu

Department of Public Health

College of Health Sciences

Debre Berhan University, Debre Berhan, Ethiopia

Phone: $+251-911373880$

Email ID:awrarishailu@gmail.com

2. Bekureamanuel Sileshi

Department of Public Health

College of Health Sciences

Debre Berhan University, Debre Berhan, Ethiopia

Phone: +251-921126478

Email ID: bekureamanuel@gmail.com

3. Hazaratali Panari

Department of Nursing

College of Health Sciences

Debre Berhan University, Debre Berhan, Ethiopia

Phone: +251-966716043

Email ID:alipanari007@gmail.com 


\section{References}

1. Marshall BJ, Warren JR, Unidentified curved bacilli on gastric epithelium in active chronic gastritis, 1983

2. Marshall BJ, Warren JR, Unidentified curved bacilli in the stomach of patients with gastritis and peptic ulceration, June 1984.

3. Blaser MJ, who are we? Indigenous microbes and the ecology of human diseases, 2006.

4. Ofori EG, Adinortey CA, Bockarie AS..et al, Helicobacter pylori Infection, Virulence Genes' Distribution and Accompanying Clinical Outcomes: The West Africa Situation, BioMed Research International, 2019, Article ID 7312908, 13 pages https://doi.org/10.1155/2019/7312908

5. Hooi JK., Lai WY., et al, Global prevalence of Helicobacter pylori infection, systematic review and meta-analysis Gastroenterology, 2017.

6. Melese A., Genet C., Zeleke B., et al., Helicobacter pylori infections in Ethiopia; prevalence and associated factors: asystematic review and meta-analysis, BMC Gastroenterology (2019) 19:8 https://doi.org/10.1186/s12876-018-0927-3.

7. Smith S, Fowora M, Pellicano R. Infections with Helicobacter pylori and challenges encountered in Africa. World J Gastroenterol 2019; 25(25): 3183-3195.

8. Basilo ILD., et al, Risk factors of Helicobacter pylori infection in an urban community in Northeast Brazil and the relationship between the infection and gastric diseases, Rev Soc med trop, 51 (2)183189 March-April, 2018, doi10.1590/0037-8682-0412-2016

9. Khasag O., Boldbaatar G., Tegshee T, et al, the prevalence of Helicobacter pylori infection and other risk factors among Mongolian dyspeptic patients who have a high incidence and mortality rate of gastric cancer, Gut Pathog (2018) 10:14.

10. Gulcan E. M., Varol A., Kutlu T., Helicobacter pylori Stool Antigen Test, Indian J Pediatr 2005; 72 (8): 675-678.

11. Shiferaw G. and Abera D., Magnitude of Helicobacter pylori and associated risk factors among symptomatic patients attending at Jasmin internal medicine and pediatrics specialized private clinic in Addis Ababa city, Ethiopia, BMC Infectious Diseases (2019) 19:118.

12. Gebremariam A., Shimelis T., Tadewos A. et al., Prevalence and associated factors of Helicobacter pylori Infection among HIV positive adults on Antiretroviral Therapy, Vol. 11(1), pp. 1-8, January 2019 DOI: 10.5897/JAHR2018.0479 Article Number: 9814CAA59887 ISSN 2141-2359.

13. Khasag O., Boldbaatar G., Tegshee T, et al, the prevalence of Helicobacter pylori infection and other risk factors among Mongolian dyspeptic patients who have a high incidence and mortality rate of gastric cancer, Gut Pathog (2018) 10:14.

14. Hamrah M.H, Hamrah M.S, Hamrah M.H. et al., Prevalence of Helicobacter Pylori Infection in Dyspeptic Patientsin Andkhoy Afghanistan, Asian Pacific Journal of Cancer Prevention, APJCP.2017.18.11.3123 
15. Yadufashije1 C., Uwitonze A.Y., Manizabayo Y. et al., Detection of Helicobacter pylori among gastritis patients attending Nemba district hospital, Afr.J.Bio.Sc. (2019) 68-75.

16. https://doi.org/10.33472/AFJBS.1.4.2019.68-75

17. Alebie G. and Kaba D., Prevalence of helicobacter pylori infection and associated factors among gastritis students in Jigjiga University, jigjiga, somali regional state of Ethiopia, J Bacteriol Mycol Open Access. 2016; 3(3):234-239.

18. Agbor N.E, Esemu S.N, Ndip L.M et al.., Helicobacter pylori in patients with gastritis in West Cameroon: prevalence and risk factors for infection, BMC Res Notes (2018) 11:559

19. Digestive Health Foundation, Information about Helicobacter Pylori (H. pylori), Gastroenterological Sosaety of Australia, third edition August 2010.

20. Dilnessa T., Amentie M., Prevalence of Helicobacter pylori and risk factors among dyspepsia and non-dyspepsia adults at Assosa General Hospital, West Ethiopia: A comparative study, Ethiop. J. Health Dev. 2017; 31

21. Bello AK, Umar AB, Borodo MM, et al., Prevalence and risk factors for Helicobacter pylori infection in gastro duodenal diseases in Kano, Nigeria. Afr J Med Health Sci 2018; 17:41-6.

\section{Figures}

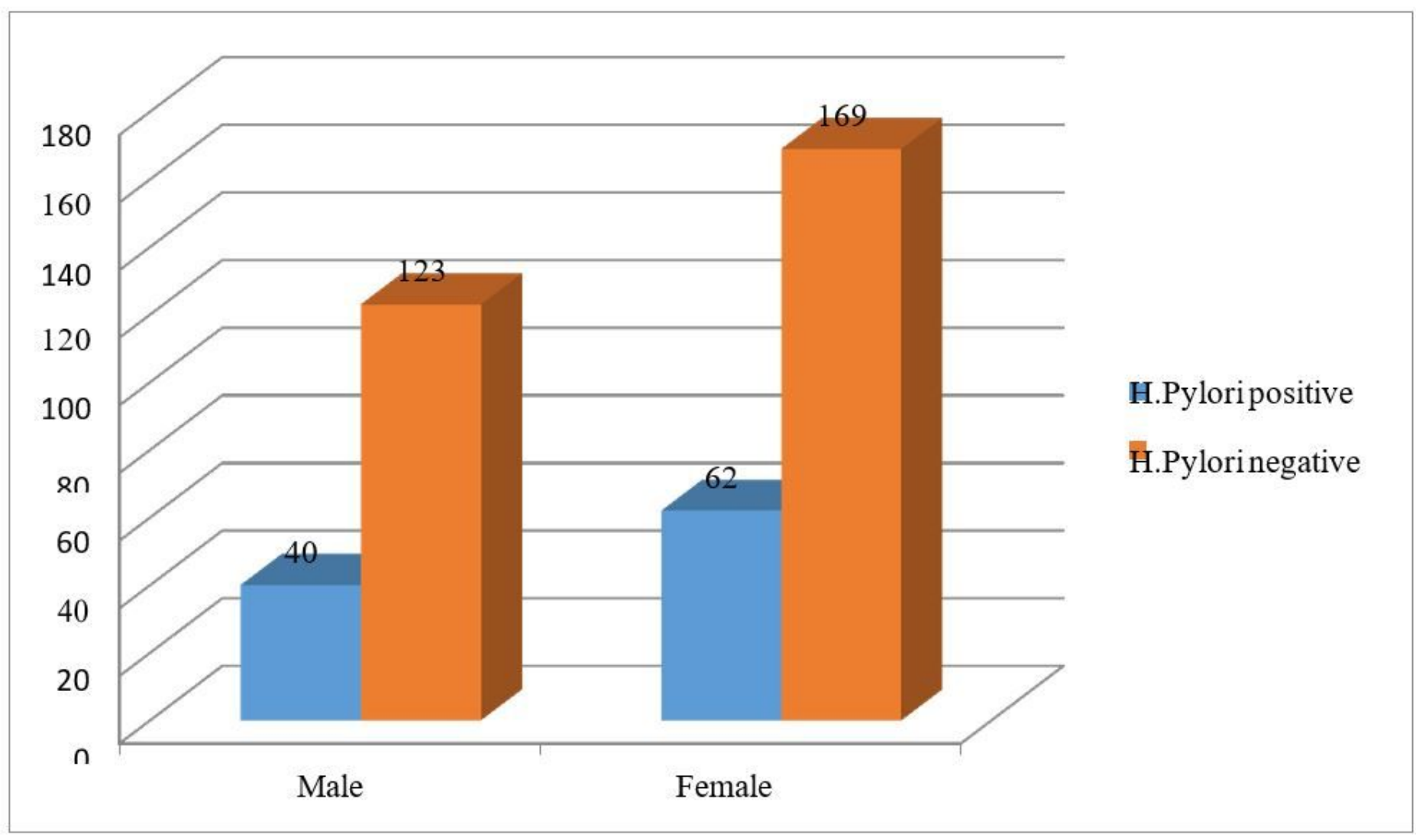

Figure 1 
H. Pylori infection among male and female gastritis patients

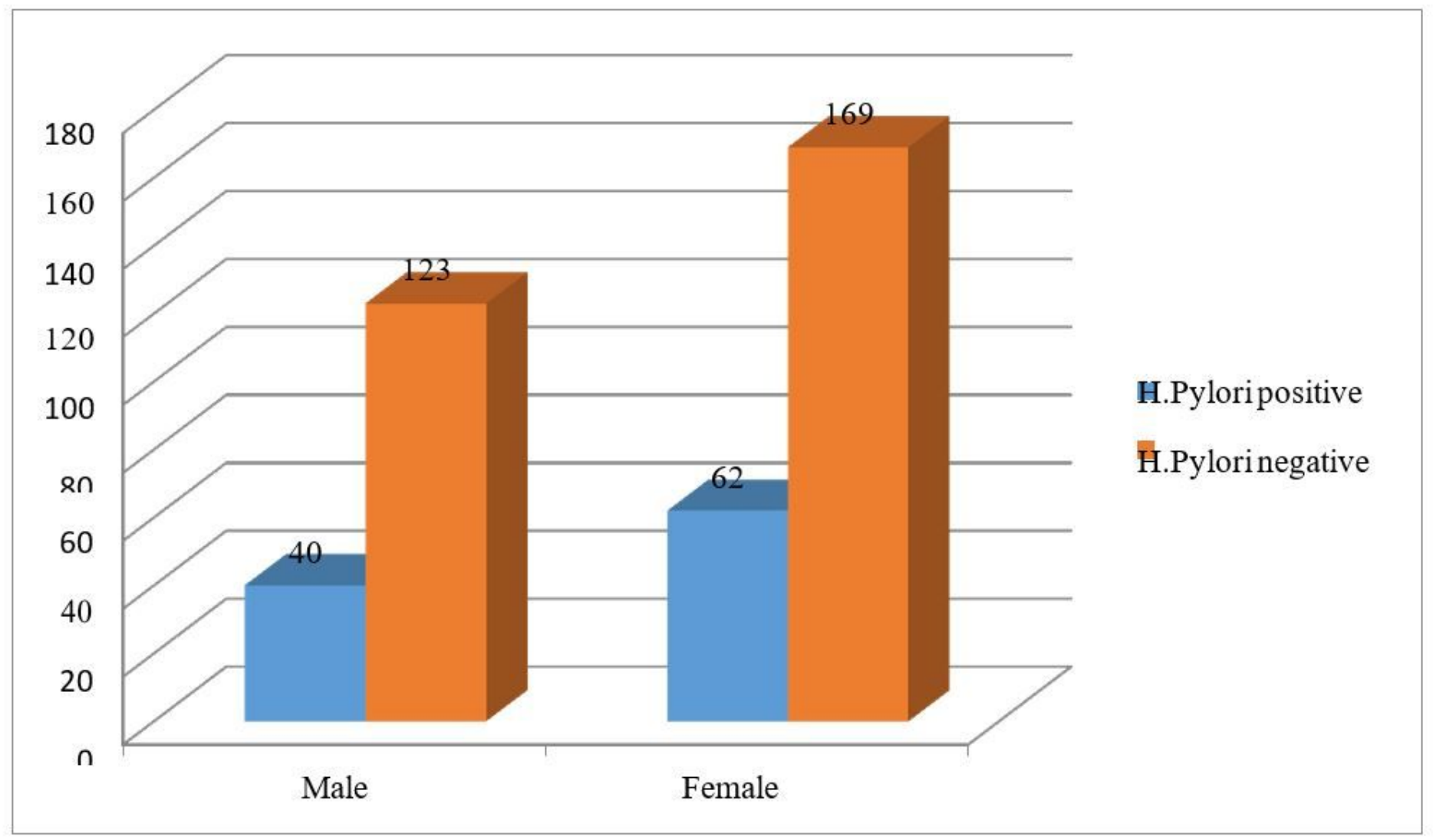

\section{Figure 1}

H. Pylori infection among male and female gastritis patients

\section{Supplementary Files}

This is a list of supplementary files associated with this preprint. Click to download.

- ANNEXURE.docX

- ANNEXURE.docX 